\title{
$\mathrm{FRP}$ 복합재료 방향타 장착 근해어선의 해상시운전시험 결과분석
}

\author{
박충환 ${ }^{*}$ 장호윤 ${ }^{*}$ 박명식 ${ }^{* *}$ 임남균 ${ }^{* * *}$ \\ *중소조선연구원 해양레저장비개발센터 \\ *대성마린텍(주) \\ ***국립목포해양대학교 해상운송시스템학부
}

\section{Result Analysis of Sea Trial Test for Offshore Fishing Boat Attached FRP Rudder}

\author{
Chung-Hwan Park, ${ }^{*}$ Ho-Yun Jang ${ }^{*}$, Myung-Sik Park ${ }^{* *}$ and Nam-Kyun Im ${ }^{* * *}$ \\ "Marine Leisure Equipment Center, RIMS, Busan, Korea \\ * Daeseong Marinetec Co. Ltd., Busan, Korea \\ ****ivision of Maritime Transportation System, Mokpo National Maritime University, Mokpo, Korea
}

KEY WORDS: FRP 유리섬유 강화 플라스틱, Composite material 복합소재, Rudder 방향타, Offshore fishing boat 근해어선, Sea trial test 해상시운전 시험

\begin{abstract}
This paper reports the results of a comparative study on rudder performance between the steel rudders that have been used in coastal angling fishing boats in the 20-GT class and the newly developed FRP composite material rudders. In order to compare the rudder performances of these two types, a sea trial test was carried out to investigate the speed performance, fuel consumption, and ship's turning ability. The results showed that the sea trial performance of the FRP composite rudder was better than that of the steel rudder type in terms of the sea speed, fuel consumption rate, and turning ability.
\end{abstract}

\section{1. 서 론}

어선어업은 연안해역의 오염, 수산물 수입개방, 유류비 인상 및 인건비 상승 등의 불안정한 국내외 주요여건 등의 원인으로 최대의 경영난에 봉착, 한계에 직면하고 있어, 기존 어선어업의 구조조정과 더불어 새로운 사회, 경제적 환경에 부응하는 친환 경 선박과 운항비 절감이 요구되고 있다(Park et al., 2001; Jo et al., 2008). 한편, 근해어선은 총톤수 10 톤 이상 140 톤 미만의 선 박으로 어업허가 규정에 선망, 저인망, 근해채낚기, 토롤 등 21 업종으로 분류되고 있으며, 근해어선은 수산자원 보호를 목적 으로 규모 상한선을 두고 있어 선형이 비대해져 저항이 증가하 고 경쟁조업에 따라 주기관 마력을 필요 이상으로 높여 고비용 저효율의 선형으로 되고 있는 실정이다. 국내 소형조선소의 설 계 및 연구 인프라의 열악함을 고려할 때 근해어선 등은 에너 지 절감 선형 및 부가물 개선, 추진시스템 효율 향상, 구조 경량 화 등의 친환경 선박 기술개발을 통한 운항비 절감은 필수적이 다. 기존 어선 관련 기술개발은 어선선미에 트림 탭 부가물을
이용하여 고속어선의 저항 및 핏칭을 개선하는 연구(Lee and Oh, 1997), 조업 중에 그물이나 부유물이 프로펠러에 감기지 않 도록 프로펠러 보호터널의 형상이 추진성능에 미치는 영향 등 의 연구를 수행한 바 있다(Suh et al., 2007). 이러한 기술 개발 목표는 대부분 선박의 저항성능 향상 및 추진 효율 향상 등으 로 소요마력 절감을 통한 연료비 절감에 중점을 두고 있다.

본 논문은 기존 연근해 어선에 장착되는 기존 사각형상의 금속 (Steel) 방향타(Rudder)와 Balanced 타입의 FRP(Fiber reinforced plastics) 방향타 형상에 따른 양력과 항력 등의 유체역학적 성 능비교를 위해 수치해석을 수행하였고, 총톤수 20ton급 근해채 낚기어선을 대상으로 동일조건에서 해상시운전 시험을 수행하 여 속력성능, 연료소비량, 선회성능을 비교, 분석한 것이다. 해 상시운전 시험결과, Balanced 타입의 FRP 방향타를 장착한 근 해채낚기어선의 속력성능, 연료소비량, 선회성능이 기존 사각형 상 금속재료 방향타(Rudder) 대비 모두 우수한 것을 확인하였 다. 향후, 2,800여척에 달하는 근해어선에 Balanced 타입의 FRP 방향타가 장착된다면 연간 운항비에서 $30 \sim 40 \%$ 를 차지하는 연

Received 17 September 2013, revised 11 December 2013, accepted 18 December 2013

Corresponding author Ho-Yun Jang : +82-51-974-5581, hyjang@rims.re.kr

(c) 2013, The Korean Society of Ocean Engineers 
료비용이 절감되어 유가상승에 따른 많은 어려움을 겪는 어민 들의 경영수지 개선에 상당한 기여를 할 것으로 판단된다.

\section{2. 금속 방향타 및 FRP 방향타}

총톤수 20ton급 근해채낚기어선에 장착된 FRP 방향타는 타면 적의 20 30\%가 회전축의 앞쪽에 있는 전형적인 Balanced 타 입으로서 타의 압력중심과 회전중심이 가까우므로 회전모우멘 트가 작고 같은 흘수에서 타의 유효단면이 크므로 타 효과가 큰 특징이 있는 방향타이다(Jun et al., 2012). 기존 어선에 장착 된 금속 방향타는 사각형상이 대부분으로 강철을 단판 또는 2 개를 겹치게 하여 중량이 무거우며 아크 및 지그용접 한 부위 는 일정시간이 지나면 떨어지거나 훼손되어 정기적으로 보수를 하게 된다. Fig. 1에 해상시운전 시험에 사용된 금속방향타와 FRP 방향타의 개략도면을 나타내었다.

한편, FRP 방향타의 제작공정은 성형몰드에 폴리우레탄 폼

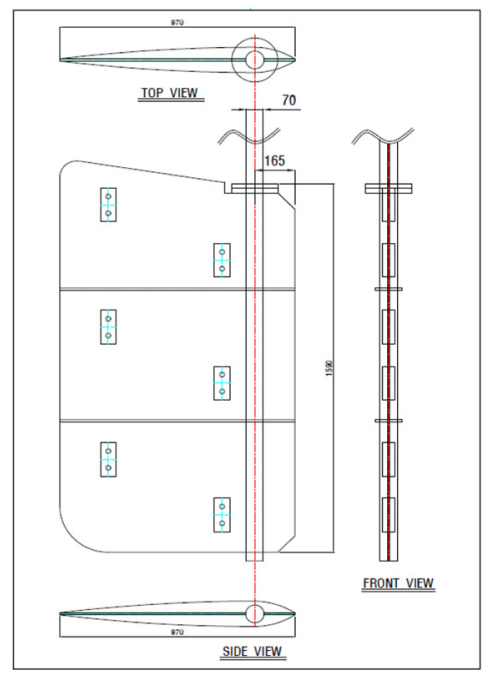

(a) Steel rudder (Type \#1)

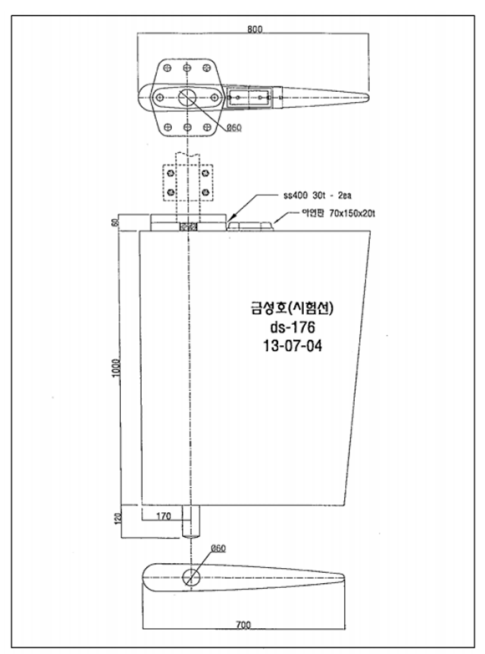

(b) FRP rudder (Type \#2)

Fig. 1 Drawing of steel rudder and FRP rudder (Wetting)
Table 1 Principal specifications of between steel rudder and FRP rudder

\begin{tabular}{|c|c|c|c|}
\hline Items & Weight & \multicolumn{2}{|c|}{ Principal dimension } \\
\hline \multirow{2}{*}{ Steel rudder } & \multirow{2}{*}{ abt. $200 \mathrm{~kg}$} & length & chord \\
\hline & & $1.0 \mathrm{~m}$ & $0.8 \mathrm{~m}$ \\
\hline \multirow{2}{*}{ FRP rudder } & \multirow{2}{*}{ abt. $100 \mathrm{~kg}$} & length & chord \\
\hline & & $1.0 \mathrm{~m}$ & $0.75 \mathrm{~m}$ \\
\hline
\end{tabular}

코어(Polyurethane foam core)를 제작하여 폼 코어 위에 유리 섬유 필라멘트(Glass filament)로 와인딩 한 후 일방향 매트 (U/D (Unidirectional) glass fiber)로 마무리하여 적층한다. 적 층된 제품은 실리콘 백으로 진공장착 후 수지성형주입기계로 불포화폴리에스터 수지를 주입하여 유리섬유를 수지에 함침시 켜, 수지가 경화(Cure) 후 탈형하여 코팅으로 마무리하였다.

(Song and Yeom, 2010; Choi et al., 2013). 시험대상 Balanced 타입의 FRP 방향타는 기존 연근해 어선에 장착된 사 각형상 금속 방향타에 비해 약 $94 \%$ 의 방향타 면적을 가지며 무 게가 $50 \%$ 정도 가볍고 고강도이며, 부식이 없고 내화성이 우수 한 것이 특징이다. Table 1에 기존 사각형상의 금속재료 방향타 와 Balanced 타입의 FRP 방향타의 주요사양을 나타내었다.

\section{3. 수치해석 결과분석}

기존 사각형상 금속재료 방향타와 Balanced 타입의 FRP 방향 타의 형상에 따른 유체역학적인 성능 비교를 위해 유한체적법 (FVM, Finite volume method)에 근거한 범용 프로그램인 플런 트(Fluent)을 사용하여 수치해석을 수행하였다. 총톤수 20톤급 근해채낚기어선에 장착되는 금속 방향타(Type \#1)와 FRP 방향 타(Type \#2)를 대상으로 어선의 운항속도 10노트에서, 방향타 의 받음각의 변화폭 $0^{\circ} \sim 30^{\circ}$ 사이에서 $5^{\circ}$ 간격으로 변화시켜 방 향타 단독의 수치해석을 각각 수행하였다. 수치해석은 금속재 료 방향타와 FRP 방향타의 격자생성을 위한 모델링 작업, 전처 리(Preprocessing), 해석(Solving), 후처리(Postprocessing) 과정 을 통하여 유체역학적 성능 파악 및 분석을 수행하였다. 금속 및 FRP 방향타 2가지 방향타의 수치해석을 수행하기 위한 3 차 원 형상작업을 수행하였으며, Fig. 2에 금속 및 FRP 방향타를 각각 도시하였다.

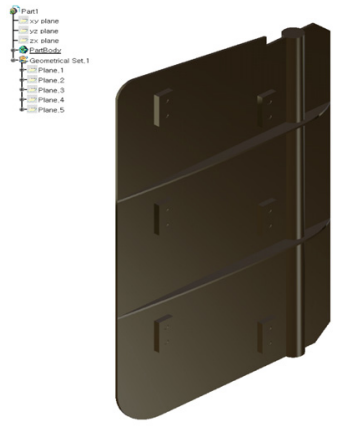

(a) Steel rudder (Type \#1)
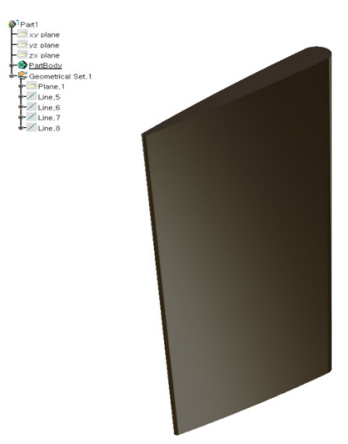

(b) FRP rudder (Type \#2)
Fig. 2 Modeling of steel rudder and FRP rudder 
Table 2 Hydrodynamic performance

\begin{tabular}{|c|c|c|c|c|c|c|c|}
\hline Type & Speed & Angle & $\operatorname{Lift}(\mathrm{N})$ & $\operatorname{Drag}(\mathrm{N})$ & $C_{L}$ & $C_{D}$ & $C_{L} / C_{D}$ \\
\hline \multirow{7}{*}{$\begin{array}{l}\text { Steel rudder } \\
\text { (Type } \# 1)\end{array}$} & \multirow{7}{*}{10 knots } & $0^{\circ}$ & 2.4 & 947.1 & 0.000 & 0.020 & 0.003 \\
\hline & & $5^{\circ}$ & 5751.2 & 1429.5 & 0.120 & 0.030 & 4.023 \\
\hline & & $10^{\circ}$ & 13475.3 & 3019.3 & 0.281 & 0.063 & 4.463 \\
\hline & & $15^{\circ}$ & 21095.6 & 6172.2 & 0.440 & 0.129 & 3.418 \\
\hline & & $20^{\circ}$ & 20215.8 & 7885.1 & 0.422 & 0.164 & 2.564 \\
\hline & & $25^{\circ}$ & 20953.7 & 10317.7 & 0.437 & 0.215 & 2.031 \\
\hline & & $30^{\circ}$ & 23370.9 & 14011.3 & 0.487 & 0.292 & 1.668 \\
\hline \multirow{7}{*}{$\begin{array}{l}\text { FRP rudder } \\
\text { (Type \#2) }\end{array}$} & \multirow{7}{*}{10 knots } & $0^{\circ}$ & 41.5 & 434.6 & 0.001 & 0.013 & 0.096 \\
\hline & & $5^{\circ}$ & 4704.3 & 593.2 & 0.136 & 0.017 & 7.930 \\
\hline & & $10^{\circ}$ & 10538.3 & 1371.2 & 0.306 & 0.040 & 7.686 \\
\hline & & $15^{\circ}$ & 16805.3 & 3201.9 & 0.488 & 0.093 & 5.248 \\
\hline & & $20^{\circ}$ & 22411.1 & 6694.2 & 0.650 & 0.194 & 3.348 \\
\hline & & $25^{\circ}$ & 19735.9 & 10085.8 & 0.573 & 0.293 & 1.957 \\
\hline & & $30^{\circ}$ & 14478.2 & 14412.1 & 0.420 & 0.418 & 1.005 \\
\hline
\end{tabular}

수치해석 결과, 사각형상의 금속 방향타 대비 Balanced 타입 의 FRP 방향타가 전반적으로 양력계수 $\left(C_{L}\right)$ 는 증가하고, 항력 계수 $\left.\left(C_{D}\right)\right)$ 는 타각 $20^{\circ}$ 이상에서는 증가하는 경향을 보이지만, 직진 운항 시는 대부분 미소 타각을 유지하므로 Balanced 타입 의 FRP 방향타가 상대적으로 항력계수가 감소할 것으로 판단 된다. 이에 따른 양항비 $\left(C_{L} / C_{D}\right)$ 도 Balanced 타입의 FRP 방향

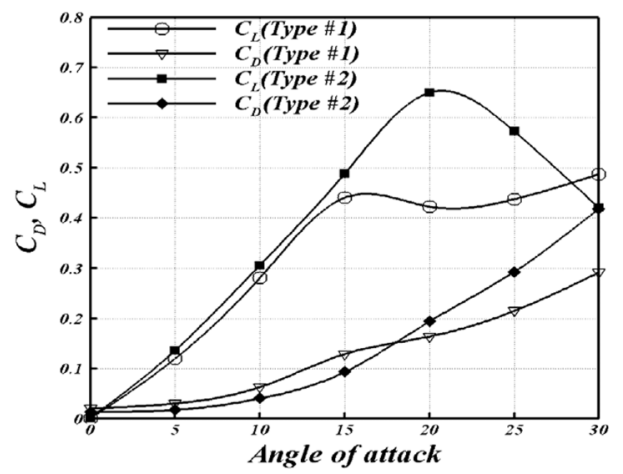

Fig. 3 Lift \& Drag coefficients of 10knots

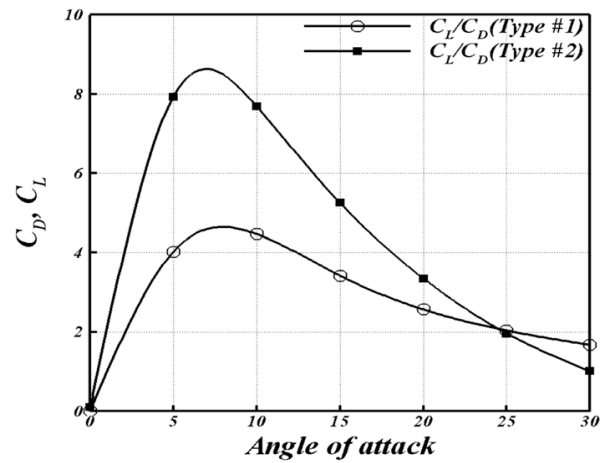

Fig. 4 Lift to Drag Coefficients of 10knots
타가 기존 사각형상의 금속 방향타보다 약 2 배 이상 증가한 것 을 확인 할 수 있었다. 방향타 형상별 유체역학적 성능을 살펴 보기 위해 각 방향의 힘의 성분인 방향타의 항력(Drag), 양력 $(\mathrm{Lift})$ 값을 수치해석을 통하여 산정하고, 각각의 힘을 무차원 계수인 항력계수, 양력계수 및 양항비로 변환하여 Table 2, Fig. 3, Fig. 4에 각각 나타내었다.

\section{4. 해상시운전 시험 결과분석}

기존 사각형상 금속재료 방향타와 Balanced 타입의 FRP 방 향타 형상에 따른 성능비교를 위해 속력시험, 연료소비량, 선 회시험을 기장 대변항에서 수행하였으며 Table 3에 해상시운 전 시험조건과 대상선박, 엔진 등의 주요사양 등을 정리하였다. 또한, 기존 사각형상 금속재료 방향타와 Balanced 타입의 FRP 방향타 장착에 따른 시험대상선의 객관적인 해상시운전 시험 결과 비교를 위해 국내 소형선박 검사 공인기관인 선박안전기 술공단 검사관의 입회하에 해상시운전 시험이 진행되었으며, Fig. 5는 해상시운전 시험에 사용된 총톤수 20ton급 근해채낚 기어선의 모습이다.

Table 3 Test conditions of sea trial and principal specifications

\begin{tabular}{ccccc}
\hline \hline Test date & 2013. 8. 6. & Test area & Busan ki-jang \\
\hline Wave height & \multicolumn{2}{c}{$0.5 \mathrm{~m}$} & Wind vel. & $4.2 \mathrm{~m} / \mathrm{s}$ \\
\hline & $\mathrm{L}$ & $17.8 \mathrm{~m}$ & $\mathrm{G} / \mathrm{T}$ & $20 \mathrm{ton}$ \\
Dimension & B & $4.2 \mathrm{~m}$ & Fuel Capa. & $\begin{array}{c}1.8(\mathrm{~L}) \times 1.8(\mathrm{~B}) \\
\times 1.09(\mathrm{D}) \mathrm{m}\end{array}$ \\
& $\mathrm{D}$ & $1.72 \mathrm{~m}$ & Person & 11 \\
\hline Engine Spe. & \multicolumn{3}{c}{$1,800 \mathrm{rpm} \times 380 \mathrm{HP}$} \\
\hline
\end{tabular}




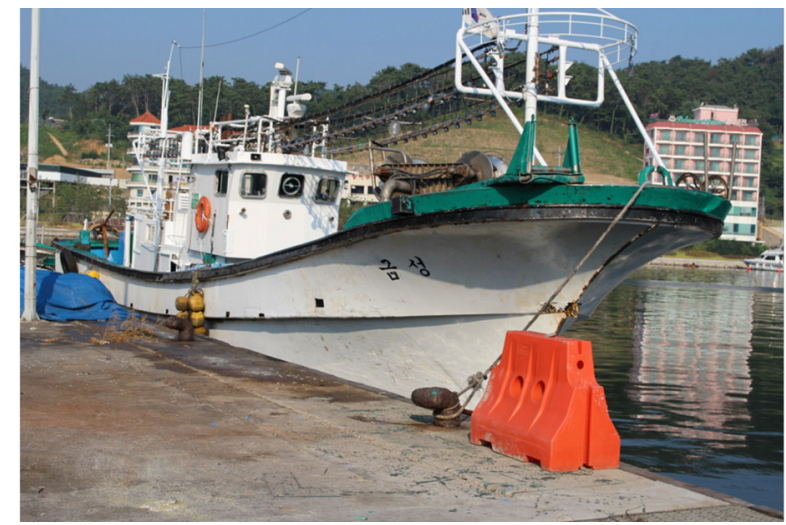

Fig. 5 Photo of G/T 20ton fishing vessel

\section{1 속력시험}

기존 사각형상 금속재료 방향타와 Balanced 타입의 FRP 방 향타를 장착한 근해채낚기어선의 속력성능 비교, 평가를 위해 속력시험을 수행하였으며, 속력계측은 DGPS(Differential global positioning system 속력계측장비를 이용하여 계측하였다. 속 력시험은 기존 사각형상 금속재료 방향타와 Balanced 타입의 FRP 방향타 장착에 따른 어선의 속력성능 비교, 평가를 위해 수행된 것으로서 시험대상 근해채낚기어선의 동일 프로펠러 회전수에서의 속력을 계측하였다. 본 어선의 최대출력은 380 마력으로서 프로펠러 회전수는 연속최대출력(MCR)에 해당하 는 동일한 $1,750 \mathrm{rpm}$ 과 동일한 3 마일 운항거리에서 속력 계측 장비를 이용하여 기존 사각형상 금속 방향타와 Balanced 타입 의 FRP 방향타를 장착한 어선의 선속을 계측하였다. Fig. 6과 Fig. 7은 속력시험에 사용된 속력계측장비의 신호체계와 구성 도이다.

속력시험 결과, 기존 사각형상 금속재료 방향타와 Balanced 타입의 FRP 방향타를 장착한 근해채낚기어선의 3 mile 왕복 주 행거리의 평균선속은 Table 4 에 보듯이 각각 $10,205 \mathrm{Knot}$ 와 $10.766 \mathrm{Knot}$ 로 계측되어 Balanced 타입의 FRP 방향타 장착어 선이 기존 사각형상 금속재료 방향타 부착 어선에 비해 저항 감소에 따른 선속증가율이 $5.5 \%$ 로 향상되었다. 이를 통해 Balanced 타입의 FRP 방향타가 기존 사각형상 금속재료 방향

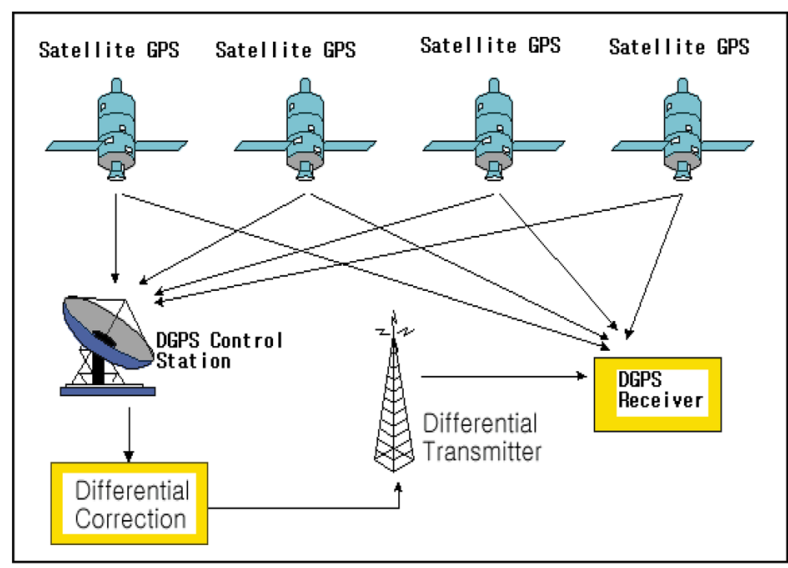

Fig. 6 DGPS signal scope

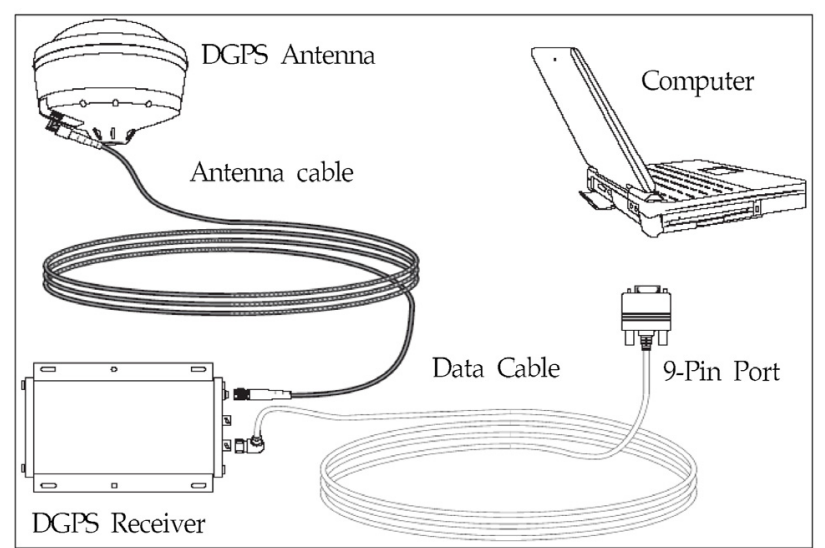

Fig. 7 Measuring diagram

Table 4 Result of speed trial

\begin{tabular}{|c|c|c|c|c|}
\hline Items & $\begin{array}{c}\text { Propeller } \\
\text { RPM }\end{array}$ & $\begin{array}{l}\text { Ship } \\
\text { speed }\end{array}$ & $\begin{array}{l}\text { Mean } \\
\text { speed }\end{array}$ & $\begin{array}{l}\text { Rate of } \\
\text { increase }\end{array}$ \\
\hline \multirow{2}{*}{ Steel rudder } & \multirow{4}{*}{$\begin{array}{c}1,750 \\
(\mathrm{MCR})\end{array}$} & $11.485 \mathrm{kt}$ & \multirow{2}{*}{$10.205 \mathrm{Kt}$} & \\
\hline & & $8.925 \mathrm{kt}$ & & \\
\hline \multirow{2}{*}{ FRP rudder } & & $10.659 \mathrm{kt}$ & \multirow{2}{*}{$10.766 \mathrm{Kt}$} & \multirow{2}{*}{$5.5 \%$} \\
\hline & & $10.873 \mathrm{kt}$ & & \\
\hline
\end{tabular}

타에 비해 저항성능이 우수한 방향타임을 확인하였다. Fig. 8은 기존 사각형상 금속 방향타와 Balanced 타입의 FRP 방향타의 왕복운항별 속력시험 결과도표이다.

\section{2 연료소비량 계측}

기존 사각형상 금속 방향타와 Balanced 타입의 FRP 방향타 를 장착한 총톤수 20 톤급 근해채낚기어선의 동일한 프로펠러 회전수(1,750rpm)와 12마일 운항거리에서 유량계측기를 이용 하여 기존 금속재료 방향타와 FRP 방향타 형상에 따른 연료소 비량을 비교, 검토하였다. 연료소비량 계측결과, 총 운항거리 12 마일에서 사각형상 금속재료 방향타와 Balanced 타입의 FRP 방향타를 장착한 근해채낚기어선의 연료소비량은 각각 $324 l$ 와 $304 l$ 로 계측되었으며, 소요시간도 Balanced 타입의 FRP 방향 타 장착 어선이 사각형상 금속재료 방향타 장착 어선에 비해 약 16 분 정도가 단축되었다. Table 5 는 기존 사각형상 금속재 료 방향타와 Balanced 타입의 FRP 방향타를 장착한 총톤수 20 톤급 근해채낚기어선의 소요시간과 연료소비량 계측결과 등을 나타내었다.

Table 5 Result of fuel consumption

\begin{tabular}{|c|c|c|c|c|}
\hline Items & $\begin{array}{c}\text { Propeller } \\
\text { RPM }\end{array}$ & $\begin{array}{l}\text { Sailing } \\
\text { distance }\end{array}$ & $\begin{array}{l}\text { Use } \\
\text { time }\end{array}$ & $\begin{array}{c}\text { Fuel } \\
\text { consumption }\end{array}$ \\
\hline Steel & \multirow{2}{*}{$\begin{array}{l}1,750 \\
\text { (MCR) }\end{array}$} & \multirow{2}{*}{$\begin{array}{c}\text { 12mile } \\
(19.3 \mathrm{~km})\end{array}$} & $78 \mathrm{~min}$. & $324 l$ \\
\hline FRP & & & $62 \mathrm{~min}$. & $304 l$ \\
\hline
\end{tabular}




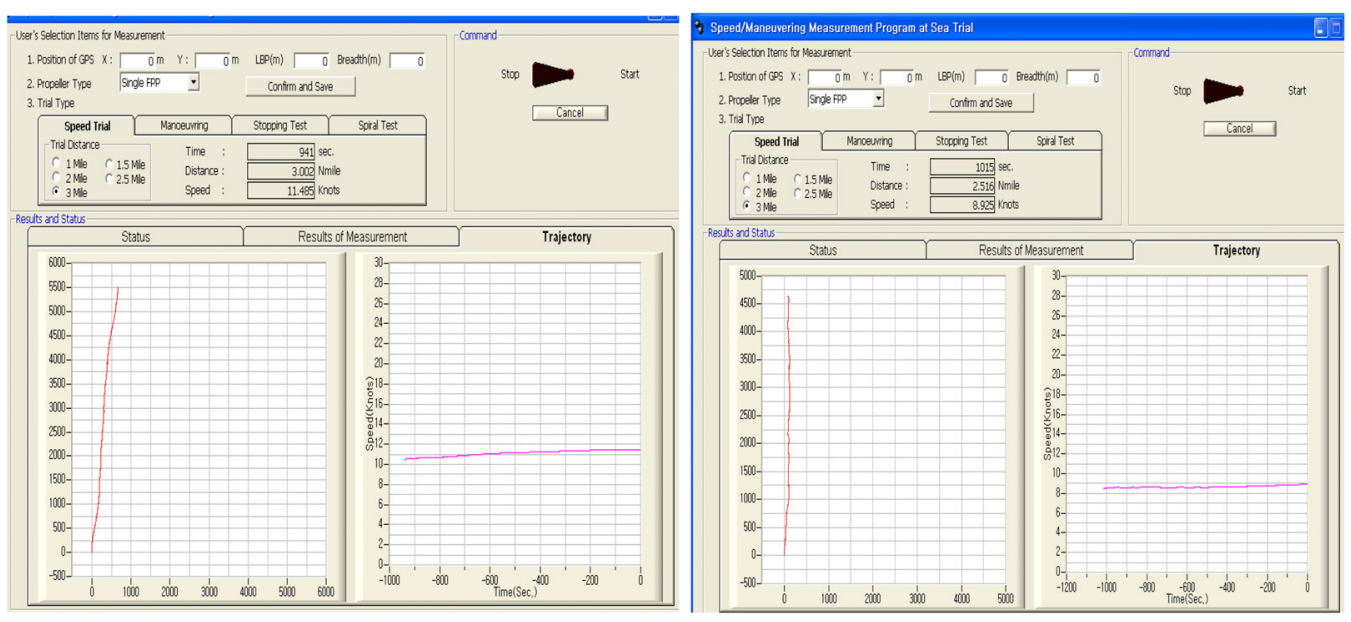

(a) Steel rudder

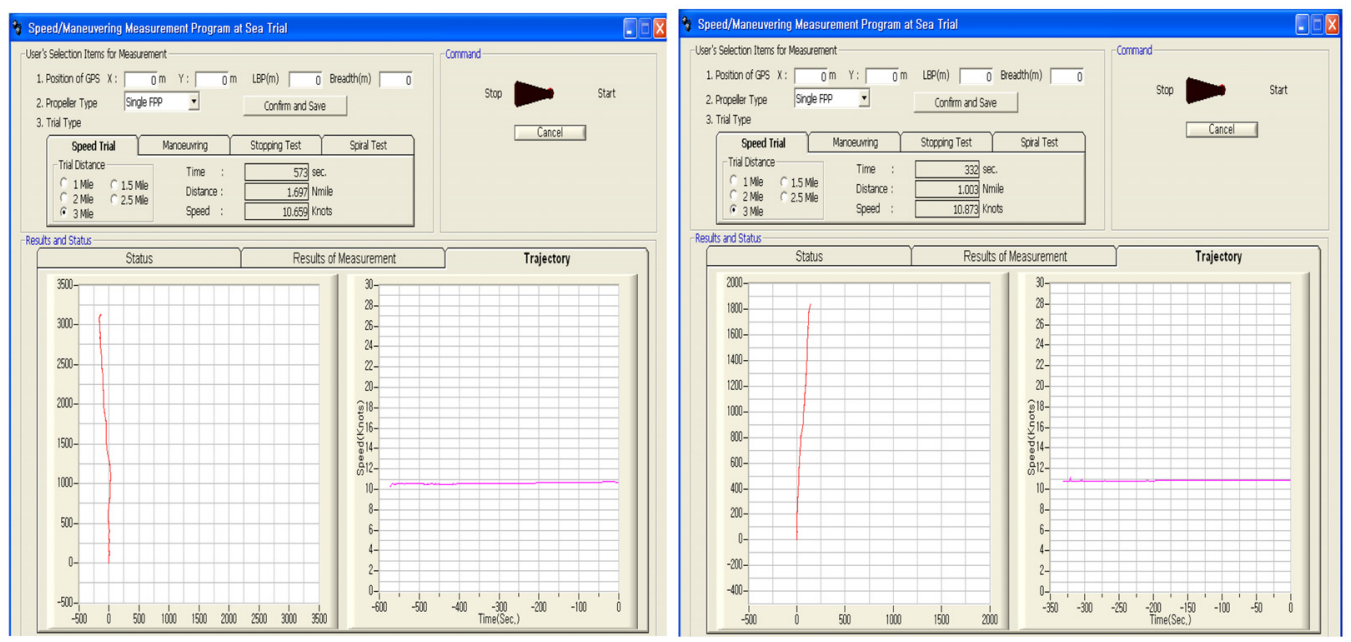

(b) FRP rudder

Fig. 8 Result diagram of speed test for steel rudder and FRP rudder

이에 따라 Balanced 타입의 FRP 방향타 장착어선의 연료소 비량이 기존 사각형상 금속재료 방향타에 비해 약 $6.2 \%$ 로 감 소되었으며, 총 12 마일 운항거리에서는 $20 l$ 의 연료량 감소를 보여 Balanced 타입의 FRP 방향타가 기존 사각형상 금속재료 방향타에 비해 연료소비량 감소에 유리한 방향타임을 확인하 였다.

\section{3 선회시험}

선회시험(turning test)은 선박 방향타의 선회 조종능력, 최대 선회지름 등을 파악하여 방향타의 성능을 확인할 수 있는 매우 중요한 시험으로서 소형선에는 기준이 적용되지 않지만, 대형 선박을 대상으로 국제해사기구(IMO)에서는 전술직경(tactical diameter)이 5.0L이하이면 조종성능을 만족하는 기준을 규정하 고 있다(IMO Msc 76/23, 2002). 형상에 따른 방향타의 조타성 능 비교를 위해서 기존 사각형상 금속재료 방향타와 Balanced 타입의 FRP 방향타를 장착한 총톤수 20 톤급 근해채낚기어선을 대상으로 동일 프로펠러 회전수(1,750rpm)에서 방향타를 조타
하여 선수 머리가 $360^{\circ}$ 회전 할 때까지의 전술직경(Tactical diameter) 궤적을 계측장비(DGPS)를 이용하여 계측하였다. 선 회시험 결과, Table 6에 보듯이 기존 사각형상 금속재료 방향 타와 Balanced 타입의 FRP 방향타를 장착한 근해채낚기어선의 전술직경이 약 $122.0 \mathrm{~m}$ 와 $89.0 \mathrm{~m}$ 로 계측되어 Balanced 타입의 FRP 방향타 장착어선의 전술직경이 약 $27 \%$ 로 감소됨을 확인 할 수 있었다.

이를 통해 Balanced 타입의 FRP 방향타가 기존 사각형상 금 속 방향타에 비해 전술직경이 작아 조종(선회)성능이 우수한

Table 6 Result of turning circle test

\begin{tabular}{|c|c|c|c|}
\hline \multirow{2}{*}{$\begin{array}{l}\text { Propeller } \\
\text { RPM }\end{array}$} & \multicolumn{2}{|c|}{ Tactical diameter } & \multirow{2}{*}{$\begin{array}{l}\text { Reduction } \\
\text { ratio }\end{array}$} \\
\hline & Steel & FRP & \\
\hline $\begin{array}{l}1,750 \\
\text { (MCR) }\end{array}$ & $\begin{array}{l}\text { abt. } 122.0 \mathrm{~m} \\
(6.85 \mathrm{~L})\end{array}$ & $\begin{array}{c}\text { abt. } 89.0 \mathrm{~m} \\
(5 \mathrm{~L})\end{array}$ & abt. $27 \%$ \\
\hline
\end{tabular}




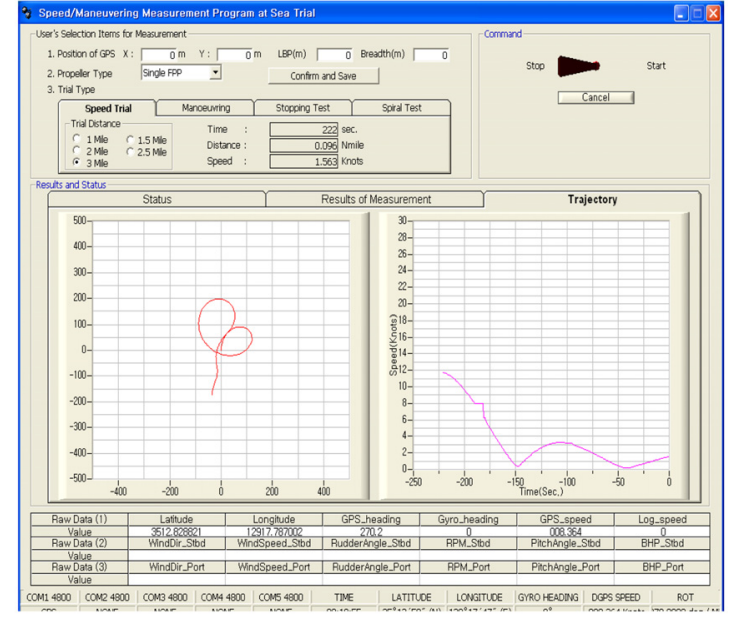

(a) Steel rudder

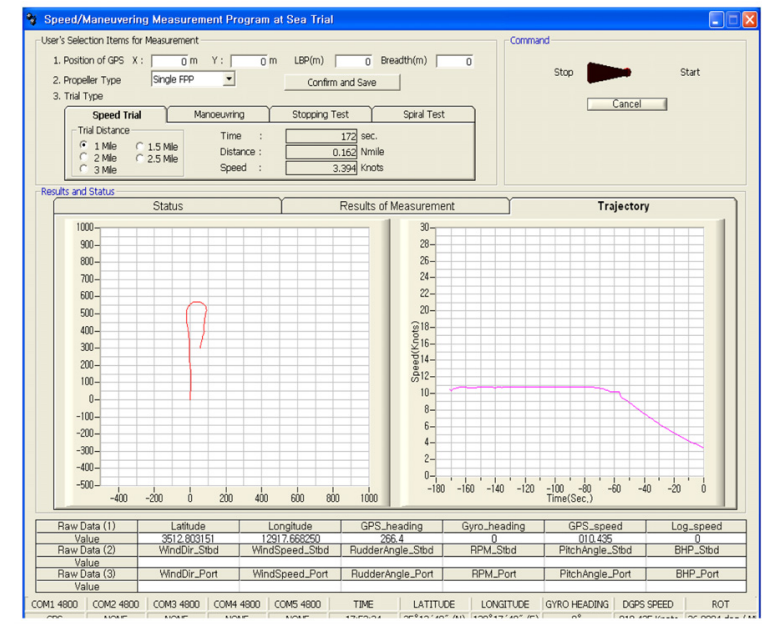

(b) FRP rudder

Fig. 10 Result diagram of turning circle test for steel rudder and FRP rudder

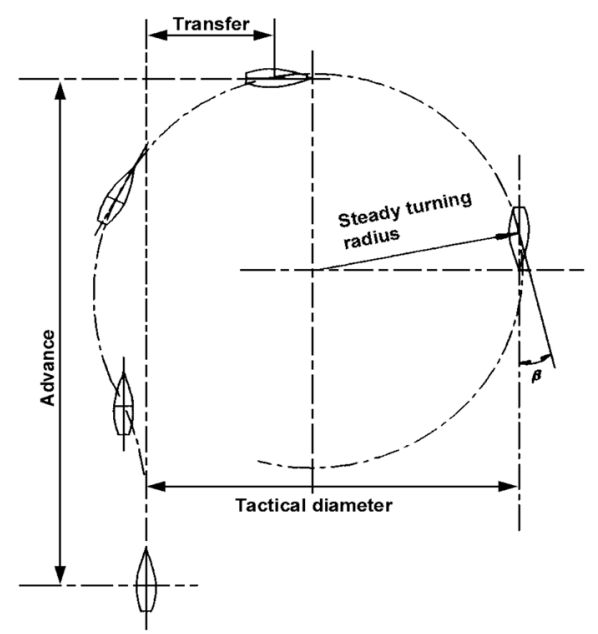

Fig. 9 Turning trajectory of turning circle test

방향타임을 확인하였다. Fig. 9는 국제해사기구(IMO)에서 선박 의 조종성능 평가를 위해서 사용되는 선회시험에 따른 이동거 리 및 선회궤적 등을 나타낸 것이며, Fig. 10은 기존 사각형상 금속재료 방향타와 Balanced 타입의 FRP 방향타의 선회성능 시험결과를 나타낸 도표이다.

\section{5. 결 론}

본 논문에서는 기존 연근해 어선에 장착되는 사각형상의 금 속 방향타와 Balanced 타입의 FRP 방향타를 대상으로 수치해 석을 통한 유체역학적 주요특성을 비교하였다. 또한, 총톤수 20 톤급 근해채낚기어선을 대상으로 기존 사각형상 금속 방향타와 Balanced 타입의 FRP 방향타를 장착하여 해상시운전 시험을 수행하여 방향타 형상에 따른 속력성능, 연료소비량, 선회성능 을 비교, 분석하였다. 방향타 형상에 따른 수치해석 및 해상시 운전 시험 결과로부터 다음과 같은 결론을 얻을 수 있었다.
(1) 해상시운전 속력시험 결과, 기존 사각형상 금속재료 방향 타와 Balanced 타입의 FRP 방향타를 장착한 근해채낚기어선의 프로펠러 회전수 $1,750 \mathrm{rpm}(\mathrm{MCR})$ 에서 동일한 3mile 왕복 주 행거리의 평균선속은 각각 $10,205 \mathrm{Knot}$ 와 $10.766 \mathrm{Knot}$ 로 계측 되어 Balanced 타입의 FRP 방향타 장착어선이 사각형상의 금 속 방향타 장착어선에 비해 저항 감소에 따른 선속증가율이 $5.5 \%$ 로 향상됨을 확인하였다.

(2) 연료소비량 계측결과, 총 운항거리 12 마일에서 기존 사각 형상 금속재료 방향타와 Balanced 타입의 FRP 방향타를 장착 한 근해채낚기어선의 연료소비량은 각각 $324 l$ 와 $304 l$ 로 계측 되었으며, 소요시간도 Balanced 타입의 FRP 방향타 장착 어 선이 기존 사각형상 금속재료 방향타 장착 어선에 비해 약 16 분 정도가 단축되었다. 이에 따라 Balanced 타입 FRP 방향타 장착어선의 연료소비량이 기존 사각형상 금속재료 방향타에 비해 약 $6.2 \%$ 로 감소되었고, 총 12 마일 운항거리에서 $20 l / 1.2 \mathrm{~h}$ 의 연료량 감소를 감안하여 하루 조업 8 시간 기준으로 계산하 면 약 $130 \mathrm{l} / 8 \mathrm{~h}$ 의 연료소비량이 감소될 것으로 사료된다.

(3) 선회시험 결과, 사각형상 방향타와 Balanced 타입의 FRP 방향타를 장착한 근해채낚기어선의 전술직경이 약 $122.0 \mathrm{~m}$ 와 $89.0 \mathrm{~m}$ 로 계측되어 Balanced 타입의 FRP 방향타 장 착어선의 전술직경이 약 $27 \%$ 로 감소됨을 확인할 수 있었다. 이를 통해 Balanced 타입의 FRP 방향타가 사각형상의 금속재 료 방향타에 비해 전술직경이 작아 선회성능이 우수한 방향타 임을 확인하였다.

(4) 주요원인으로는 수치해석 결과에서도 알 수 있듯이 표면 조도와 단면형상의 차이로 인하여 Balanced 타입의 FRP 방향 타가 기존 사각형상의 금속재료 방향타에 비해 양력계수 $\left(C_{L}\right)$ 는 증가하지만, 항력계수 $\left(C_{D}\right)$ 가 감소하고 이에 따라 양항비 $\left(C_{L} / C_{D}\right)$ 도 Balanced 타입의 FRP 방향타가 기존 사각형상의 금 속 방향타보다 약 2 배 이상 증가한 결과가 속력, 연료소비량, 선회시험 시운전 결과로 나타난 것으로 판단된다. 


\section{References}

Choi, H.K., Nam, K.W., Ahn, S.H., 2013. Strength Characteristics of FRP Composite Materials for Ship Structure. Journal of Ocean Engineering and Technology. 27(4), 45-54.

IMO (International maritime organization)Msc 76/23, 2002. Resolution MSC.137(76), Standards for Ship Maneuverability. Report of the Maritime Safety Committee 76th Session-annex 6.

Jo, K.H., Ham, Y.J., Park, C.H., Kwak, J.H., Oh, J.S., 2008. Design of Hybyid Propulsion System for Fishing Boat. Proceeding of the Annual Spring Meeting the Korean Society of Marine Engineering. 351-352.

Jun, H.C., Kim, S.H., Kim, H.J., Park, H.P., 2012. A Experimental Study on the Effect of Increasing Rudder Force on Turning Ability of Short Sea Shipping Ship. Journal of the Korean Society of Marine Environment \&
Safety. 18(6), 591-596.

Lee, K.J., Oh, H.T., 1997. A Study on the Development of Resistance and Pitching Improving Device for High speed Fishing Vessel. Journal of Ocean Engineering and Technolpgy. 11(3), 89-94.

Park, C.H., Choi, N.K., Suh, S.B., Jo, H.J., 2001. Resistance \& Self-Propulsion Characteristics of Single Fleet Purse Seiner. Proceeding of the Annual Spring Meeting SNAK. 375-380.

Song, H.C., Yum, J.S., 2010. A Study of the Mechanical Properties of Fiberglass Reinforcements with Constitution of Lay-up, Manufacturing Method, and Resins. Journal of Ocean Engineering and Technology. 24(5), 75-80.

Suh, S.B., Park, C.H., Moon, I.S., 2007. Experimental Investigation For Various Propeller Tunnel Geometry Effect On Propulsion Performance. Journal of Ocean Engineering and Technology. 21(3), 40-45. 